\title{
AMÉRICA LÍRICA E POÉTICA DE JACK KÉROUAC - ON THE ROAD - PÉ NA ESTRADA
}

\section{LYRICAL AND POETIC AMERICA FROM THE JACK KÉROUAC'S ON THE ROAD}

\section{AMÉRICA LÍTICA Y POÉTICA DEL LIBRO EN EL CAMINO DE JACK KÉROUAC}

\author{
Maria Geralda de Almeida ${ }^{1}$ \\ Universidade Federal de Goiás, Goiânia, Brasil
}

\begin{abstract}
Resumo: Na perspectiva de ampliar as discussões sobre o imaginário e as geografias poéticas, o propósito deste texto é evidenciar formas de compreensão geográfica do livro On the road. O olhar descobridor procurará entrever o contexto no qual subjaz o texto de Kérouac e apreender "como" a América é percebida e revelada na arquitetura textual e na criação de linguagem de Kérouac. Ela possui características do movimento beat, do qual Kérouac era considerado um avatar e para o qual o seu livro tornou-se uma bíblia. Duas paisagens presentificadas no romance serão destacadas neste texto: natural/rural e urbano/cidade com a apresentação de vários fragmentos ilustrativos dessas paisagens. Finaliza reafirmando as proximidades entre a literatura e a geografia sensível, sobretudo, pelo fato de ambas constituírem uma reflexão do homem sobre seu estar no mundo e em sua relação com o mundo pela forma de o viver.
\end{abstract}

Palavras-chave: Paisagem cultural; Literatura poética; Geografia sensível; Paisagemmovimento; Kérouac.

\begin{abstract}
The purpose of this text is to highlight the ways of understanding the geography of the book On the Road with a discussion on imagery and poetic geography. At first, you get a glimpse of the underlying context, which is Kérouac's grasp on "how" America is perceived and revealed, through textual architecture and the creation of language. In addition the reader will discover the characteristics of the movement beat. Kérouac was considered an avatar and this book was considered the bible. Two landscapes in the novel will be presented, natural/urban and urban/city.It concludes by reaffirming the sensitive vicinity between literature and geography, by the both the reflection of being a man in this world and mans relation to the world through the way he lives.
\end{abstract}

Keywords: Cultural landscape; Poetic literature; Sensitive geography; Movementlandscape; Kérouac.

Resumen: En la perspectiva de ampliar las discusiones sobre las geografías imaginarias y poéticas, el propósito de este texto es resaltar formas de comprensión geográfica del libro En el camino. La mirada descubierta intentará vislumbrar el contexto en el que

\footnotetext{
1 Atualmente é professora colaboradora da Universidade Federal de Sergipe, professora titular da Universidade Federal de Goiás onde é pesquisadora do Laboratório de Estudos e Pesquisas das Dinâmicas Territoriais-LABOTER.
} 
subyace el texto de Kérouac y aprehender "cómo" se percibe y revela a Estados Unidos en la arquitectura textual y la creación del lenguaje de Kérouac. Tiene características del movimiento beat, del cual Kérouac fue considerado un avatar y por el cual su libro se ha convertido en una biblia. En este texto se destacarán dos paisajes presentados en la novela: natural / rural y urbano / ciudad con la presentación de varios fragmentos ilustrativos de estos paisajes. Termina reafirmando la proximidad entre la literatura y la geografía sensible, sobre todo, porque ambos constituyen un reflejo del hombre sobre su ser en el mundo y en su relación con el mundo a través de la forma de vivirlo.

Palabras clave: Paisaje cultural; Literatura poética; Geografía sensible; Movimiento paisajístico; Kérouac.

\section{INTRODUÇÃ̃O}

Durante muito tempo, a reflexão sobre o sentido da existência humana foi um apanágio dos teólogos, dos filósofos, dos antropólogos, mas raramente dos geógrafos. Exceção feita a Marcel Planhol, que nos anos de 1960 fez uma tese suis generis na geografia ao interpretar o mundo islâmico. Na década de 1970 a Geografia Humanista propõe valorizar a subjetividade e recuperar a habilidade descritiva de Humboldt, cuja obra data fins do século XIX, e de Vidal de La Blache, no início do século XX. Atualmente, com as novas correntes teóricas, aceitáveis para as leituras geográficas, tornam-se mais frequente as reflexões incluírem os ideais de vida, os valores espirituais e morais organizadores do espaço; e, também, o imaginário que o envolve.

A abordagem cultural valoriza o estudo dos lugares como sítios da experiência humana individual ou coletiva, que se traduz em valores particulares manifestados nas obras de arte, em particular, na literatura. Contemporaneamente, a reflexão na geografia amplia sua escala e se interessa para estabelecer interlocução multidisciplinar (PITTE, 2006), de modo que a literatura passa a constituir um destes novos interlocutores da geografia.

A literatura é considerada uma fonte de imaginação científica, de motivação intelectual, capaz de despertar desejos, de influenciar os gostos e de provocar ações. Ela é vista, também, como uma forma de linguagem, capaz de transmitir sentimentos. E, porque ela é linguagem, "enuncia uma experiência humana do mundo", como afirma Tissier (1992, p. 238). Porém, quem apresenta uma concepção de literatura em toda sua plenitude é Candido: "literatura é um instrumento poderoso de instrução e educação. Ela 
confirma e nega; propõe e denuncia; apoia e combate, fornecendo a possibilidade de vivermos dialeticamente os problemas. Ela tem papel formador da personalidade" (CANDIDO, 2004, p. 18).

O mundo possui uma "escritura" que o poeta revela. O poeta dá a voz e desvela o escrito. Dardel, no seu livro "Homem e a Terra", refere-se a essa qualidade do poeta qualificando-a com o termo invocação. É pelo ato de ler e de escrever que Dardel expressa como a geografia tem um elo forte com a literatura.

Neste artigo, o propósito é fazer uma apresentação da paisagem e do lirismo do On the road, romance de Jack Kérouac. Neste exercício de compreensão geográfica do On the road, procurará entrever o contexto no qual subjaz o texto de Kérouac. Também, a interpretação supõe apreender "como" a América é percebida e evidenciada na arquitetura textual e no trabalho do autor e "como" a geografia aflora. O texto e a linguagem foram os roteiros norteadores para a interpretação. Duas paisagens presentificadas no romance serão destacadas para esta leitura: a natural/rural e a urbana/cidade.

A criação literária enriquece e completa a "realidade" que interessa aos geógrafos. Para Monteiro (2002), os bons escritores são como testemunhos de seu tempo, retratam aspectos que tiveram "lugar". Geógrafos e escritores compartilham esta visão singular sobre o lugar, produzido pelos homens e resultado, também, da vida.

Para o exercício, o texto se iniciará pela discussão sobre a literatura, a imaginação e os textos poéticos, desdobrando-se para abordar a relação dela com a geografia sensível; ainda neste preâmbulo conduzir-se-á para brevemente tratar como os geógrafos lidam com a literatura como forma de expressão ou como forma de interpretação.

Posteriormente, será apresentado o movimento no qual Kérouac fez sua obra e, será evidenciado como o movimento beat foi criador do On the road e como tal movimento espelha uma ideologia. Finalmente, a geografia do autor será evidenciada pois, serão expostos fragmentos ilustrativos do lirismo, da poesia na paisagem natural/rural e cidade descrita na narrativa de Kérouac. Cabe esclarecer que, no livro, há um capítulo sobre a viagem dele feita ao México, contudo, este artigo se limitará a abordar aqueles que narram sobre a viagem aos Estados Unidos. 
Esta discussão se apoia na paisagem-móvel, uma paisagem que ganha relevância com a extrema mobilidade espacial adquirida pelas sociedades. Sua característica principal é a paisagem mover-se, deslocar-se e, em On the road, em conseqüência das viagens de Kérouac.

\section{CRIAÇÃO POÉTICA E TEXTO METAFÓRICO}

O conceito de literatura corresponde à criação estética, a textos que fogem da linguagem comum, proporcionando prazer estético por sua forma, conteúdo e organização do conjunto.

Primeiramente, é importante compreender o fenômeno literário como um processo dinâmico que requer cumplicidade do leitor. Por ela, é possível que a leitura de uma obra em prosa ou em poesia sinalize os caminhos possíveis e ofereça as pistas para se desvendar significados latentes. Calobrezi (2005) pondera que a abordagem de um texto literário é semelhante a um ritual amoroso, suscita a troca, a doação de saberes e percepções mútuas.

É bastante complexo dar conta da análise interpretativa de uma obra literária. As posturas críticas divergem de acordo com os recursos e pontos de vista utilizados e apontam vários caminhos quer enfatizando a análise formal quer atentando mais aos fatores externos: individuais (o autor), sociais (época) e psíquicos. Além dessa possibilidade a abordagem de uma obra de ficção, o caráter polissêmico do texto também oferece outras formas de interpretação.

O texto é mais que seu enredo e narrativa. Seu compromisso está na poiésis, na construção de um mundo. E, no deslindamento desse universo, o próprio texto direciona o interlocutor para a significação, razão pela qual o leitor deverá despojar-se de preconceitos ou ideias pré-concebidas que impediriam a apreensão do verdadeiro sentido latente. O leitor deve munir-se de um olhar descobridor, disposto a "enxergar" as significações implícitas nos interstícios textuais. Daí Calobrezi (2005, p. 83) afirmar que "é o texto que escolhe seus leitores e não o inverso".

A obra literária pode ser considerada um testemunho sobre uma realidade mascarada ou inacessível. A literatura, ou melhor, uma dada leitura dessa realidade permite acessar um certo estado do fenômeno ou do lugar. O texto lido representa uma substituição à investigação in-situ. Exemplos dessa função compensadora da literatura 
está presente no "conhecimento" adquirido dos Sertões, pela obra de Euclides da Cunha, dos pampas gaúchos nos livros de Érico Veríssimo, especificamente $O$ Tempo e o Vento, $e$ as práticas culturais da Bahia pela obra de Jorge Amado, para citar alguns exemplos.

O campo literário é rico em gêneros literários que estabelecem com os lugares relações sutis. Os geógrafos são pouco sensíveis a essas diferenças, vítimas que são da hegemonia romanesca. Sem entrar nos debates fundamentais da teoria literária sobre a noção de gênero, sobre a pertinência da distinção "genérica", pode-se admitir que os gêneros existem e que os autores e os leitores os buscam, os evitam ou com eles se identificam. No momento da escolha, da escrita ou da leitura, o récit, o romance, o poema são, cada um no seu gênero, uma certa promessa de relação com o mundo.

O romance tem a particularidade de ser parte de uma rede com seu referencial social, geográfico e político particular, mas se situando em um conjunto mais vasto e recebendo dele uma carga de significação. Um só caminho é suficiente no romance para colocar em movimento um personagem.

Cada gênero abre uma janela. O romance abre a janela mais ampla, graças ao escritor que procura, simultaneamente, apresentar a imagem do mundo e o prazer do texto. Balzac é considerado um proponente de itinerários múltiplos e alguns romances como Ilusions perdues são de trocas de personagens, carrefours sociais. Ele multiplica as paisagens, os lugares e os trajetos. Há uma articulação de cenas da vida privada parisiense e provinciana. O romance, contudo, nem sempre oferece as belas evidências geográficas que Balzac propunha, mas o gênero jamais rompeu com essa necessidade vital que constitui um espaço ficcional formado de lugares e das relações estabelecidas entre eles pelos personagens. Assim, admite-se que a imagem poética não informa, mas transforma, instantaneamente e de maneira durável, nossa abordagem do mundo.

Quando essa mutação se opera, é menos sobre o discurso geográfico em si do que sobre a maneira de ser geógrafo.

A experiência poética conduz a atentar mais ao mundo e à linguagem. A atenção é essa forma particular da percepção que coloca em evidência um objeto, que realiza uma escolha e estabelece uma hierarquia no mundo percebido: o que merece o olhar atento, o que é digno de atenção e aquilo que é percebido de forma vaga, indistinta, para fazer aparecer o que já existia, sem mudar o sentido do conjunto. 


\section{GEOGRAFIA SENSÍVEL E LITERATURA}

A geografia romanesca tal como On the road, empresta da geografia da realidade suas toponímias, sua qualidade paisagística, seu conteúdo humano; e lhe restitui com sentido esse interesse composto da literatura, que faz do bom leitor um geógrafo sensível.

Segundo Tissier (1992, p. 248), existem momentos poéticos nos romances, "registros que podem, como toda cumplicidade fundamentada, emocionar o geógrafo". A linguagem poética é essa operação que dá uma forma distinta, que sempre suscitará a atenção. Na geografia clássica, nas obras de Humboldt, de Vidal de La Bache e de Pierre Gourou, já existia entre eles esse olhar e observação atenta, acompanhado de um certo prazer quando liam a paisagem. Os geógrafos não têm o monopólio desse olhar especial sobre o mundo, uma vez que os pintores e os poetas têm a capacidade de observar e de exprimir à sua maneira aquilo que os geógrafos procuram fazer com a sua linguagem.

Um dos precursores do estabelecimento de relação entre Geografia e linguagem literária foi, contemporaneamente, o Kenneth White. Em 1979, ele cria o termo geopoética, uma atitude com relação ao mundo, uma afiliação à terra, que o autor via como "espírito nômade" (1987). O espírito nômade - aquele do pensador e do poeta se coloca, sobretudo, como a figura intelectual chave do fim do século XX. White faz alusões breves à geografia, percorre de um saber a outro, vagueia pelos pensamentos ocidentais marginais às ciências oficiais e pelos pensamentos orientais. Com essa bagagem, ele funda uma poesia cosmográfica, reconcilia ciência e poesia, observação e imaginação.

Os adeptos da geopoética e da literatura partem do mundo como origem e como discurso. Eles falam do mundo fragmentado. Identificar as partes permite ao geógrafo dialogar melhor com a literatura para entender do poema o que a linguagem forma como figura pertinente e reconhecer o que o romance propõe como geografias simbólicas. Uma interessante análise sobre os diferentes olhares sobre natureza na obra de White foi recentemente realizada por Kozel (2012).

$\mathrm{Na}$ academia, generalizou-se a inserção dos geógrafos nas ciências pelas suas contribuições necessárias, que testemunham suas atividades e sua "razão social". Mas, 
ao se mencionar a literatura, há uma crítica sobre o desvio da geografia. Cabe lembrar, porém, que quando o geógrafo dialoga ou faz uso da literatura, ele não recusa sua formação acadêmica. Ao contrário, ele a reafirma como prática individual positiva, acompanhada de um "veja isso que sinto", maneira pessoal de assumir a sensibilidade e a cultura. A referência literária não invalida, assim, sua contribuição ao conhecimento. O recurso a literatura significa, talvez, a recusa, consciente ou não, de estabelecer uma relação com o domínio das "humanidades", inoportuna lembrança de uma idade précientífica da geografia.

A geografia, como coletividade de écrivants, deve ser mais atenta à atividade literária de seu tempo. O "escrevente" (écrivain) pode ser um vigia atencioso e um descripteur possuindo certas transformações paisagísticas e modos de vida, conforme afirma Tissier (1992).

A escritura criativa desloca e desterritorializa. Ela obriga o leitor a fazer a experiência de um mundo novo, a colocar em xeque as certezas e as causalidades do mundo antigo. A literatura incomoda, introduz no jogo das representações habituais pequenos tremores de texto da ficção e ligeiras réplicas da escritura. Esses efeitos são mais eficazes quando a obra é verdadeiramente contemporânea. São os écrivains que estão entre nós, que falam nossa língua, que respiram o mesmo ar, com quem podemos cruzar, que nos apresentam parte da experiência de um mundo que é também a nossa.

A literatura, na experiência da leitura, é um convite para refazer conhecimento. Ela estabelece relação entre um presente, o leitor, e um ausente, o autor, por intermédio de um mundo, aquele que está nos livros.

A verdade literária é diferente da verdade científica porque ela assume outras vias que não são nem impenetráveis nem misteriosas, pois dão acesso a uma compreensão do mundo. A geografia e a literatura podem se cruzar e se reconhecer porque o mundo não é um livro já escrito e seu sentido não é imediato. A literatura não cessa de dar ao mundo pela linguagem uma forma humana. A Geografia se propõe a lhe dar um sentido. Cabe, então, observar a verdade literária do romance $O n$ the road, de Kérouac.

\section{KÉROUAC E O CONTEXTO DE SUA ESCRITA}


De origem canadense e francesa, Jean-Louis Lebris de Kérouac, nasceu em Lowel, Massachusetts, em 12 de março de 1922. Declarava sua nacionalidade como franco-americana. Nos estudos universitários destacou-se principalmente no futebol. Para sobreviver, dedicou-se a diversos trabalhos como: bombeiro, colhedor de algodão, encarregado de mudanças.

Em 1944, já em Nova York, ele fez conhecimento de Allen Ginsberg e William Burroughs, que se tornaram seus companheiros de viradas noturnas nos clubes de jazz, nos quais misturavam álcool, drogas, homossexualidade, delírios poéticos e música. Nessa época, ele começa um romance: o Avant la route.

Em 1947, ele encontra seu "gêmeo" Neal Cassady e os dois cruzam os Estados Unidos. Ele se inspira desta experiência para, aditivado de grandes doses de benzedrina, escrever On the road em abril de 1951, em três semanas sobre um rolo de telex, de acordo com uma nova técnica, a "literatura do momento". O livro aparece somente em 1957 e a partir de uma resenha extremamente elogiosa do The New York Times, que o considerou a mais importante manifestação feita pela geração beat. Para aquela geração beat o Kérouac era seu avatar.

Kérouac misturou sua vida à sua obra, tornando-a substância. Ele está presente na escritura, nas recordações, nos sonhos, nas visões como se a narrativa fosse uma meditação sobre a vida.

O termo beat, Kérouac ouvira de Herbert Huncke, um marginal homossexual para quem beat definia um estado de "exaltada exaustão". Kerouac, porém, logo percebeu as múltiplas ressonâncias da palavra que significa simultaneamente "batida" (no sentido do ritmo musical), "porrada", "abatido", "exausto", "cadência do verso", "trajeto", "pilantra", e até "beatitude" que foi realmente o que despertou Kérouac para a sonoridade do vocábulo que ele adotaria. Para ele, Beat significava "a raiz, a alma, a beatitude" (BUENO, 2006, p. 241).

A Geração beat passou a referir-se a um novo movimento cultural e literário que floresceu na década de 1950, nos Estados Unidos. Tal movimento incluiu uma crítica às estruturas convencionais da sociedade, ao materialismo e à influência do puritanismo, razão pela qual defendia a experimentação de drogas, a liberdade sexual, a aproximação com a religião oriental. Ele nunca foi grande em termos de adeptos, contudo, sua influência estética e cultural foi bastante expressiva. O movimento atacou com 
veemência o formalismo quase antisséptico dos primeiros modernistas do século XX. Os beat's conseguiram produzir uma literatura que fosse mais ousada, direta e expressiva do que qualquer coisa que veio antes. Estilos de música underground, como o jazz, foram especialmente evocativas para escritores beats.

Kérouac desenvolveu seu estilo beat de maneira ímpar: era "laudatório, verborrágico, impressionista, vertiginoso, incontido, 'espontâneo', repleto de gíria, de coloquialismo" (BUENO, 2006, p. 10). Ele teve uma espécie de satori (no budismo, o "súbito despertar") ligado ao som das palavras e, desde ao primeiro manuscrito de $O n$ the road, tentava fazer com que "suas frases soassem como um solo de sax de Charlie Parker, ao som do qual escrevera a versão original do On the road" (op. cit., p. 17).

Kérouac escreveu e publicou 23 livros, nos seus 47 anos de vida. Todavia, não repetiu o sucesso obtido com o On the road. Minado pelo álcool e pelas drogas, ele começou a renegar os amigos, e o movimento beat. Em seus últimos anos, declarava publicamente suas ideias conformistas.

\section{A GEOGRAFIA DE ON THE ROAD.}

O estilo narrativo de Kérouac é avassalador, de um fluxo ininterrupto de avalanche de palavras, imagens, promessas, visões e descobertas. Conforma-se a um estilo portador de um frescor libertário, de imaginário proto-pop. Seu texto é vertiginoso, incontido, de gíria, de coloquialismo, capturando a sonoridade das ruas, das planícies e das estradas dos USA. Estava disposto a libertar a literatura norte-americana de determinadas amarras acadêmicas próprias do estilo europeu. Ao fazê-lo, introduziu o som na prosa, com frases repletas de vogais, com rima interna envolvente de forma que várias passagens se assemelham a longos poemas em prosa. On the road é um livro que se tornou a bíblia da geração beat, influenciando os movimentos de vanguarda, do be bop ao rock, ao pop, aos hippies, que sacudiram o comportamento da juventude na segunda metade do século XX. Bob Dylan, Jim Morrison, Wim Wenders, Tom Wolfe, Bono, entre outros evidenciam a fluidez veloz, as imagens sonoras e líricas no estilo de Kérouac.

On the road tem como leitmotiv as grandes viagens de dois jovens norteamericanos: Sal Paradise e Dean Moriarty. A primeira viagem apresenta como percurso a lendária Rota 66, de Paterson, de New Jersey até a costa oeste dos Estados Unidos; a 
segunda, de Testement, de Virginia até Washington, pela 301; a terceira, de Denver para Frisco e retorno para Nova York e, de Nova York até a cidade do México.

Figura 1: Mapa do Trajeto das viagens pelos Estados Unidos.

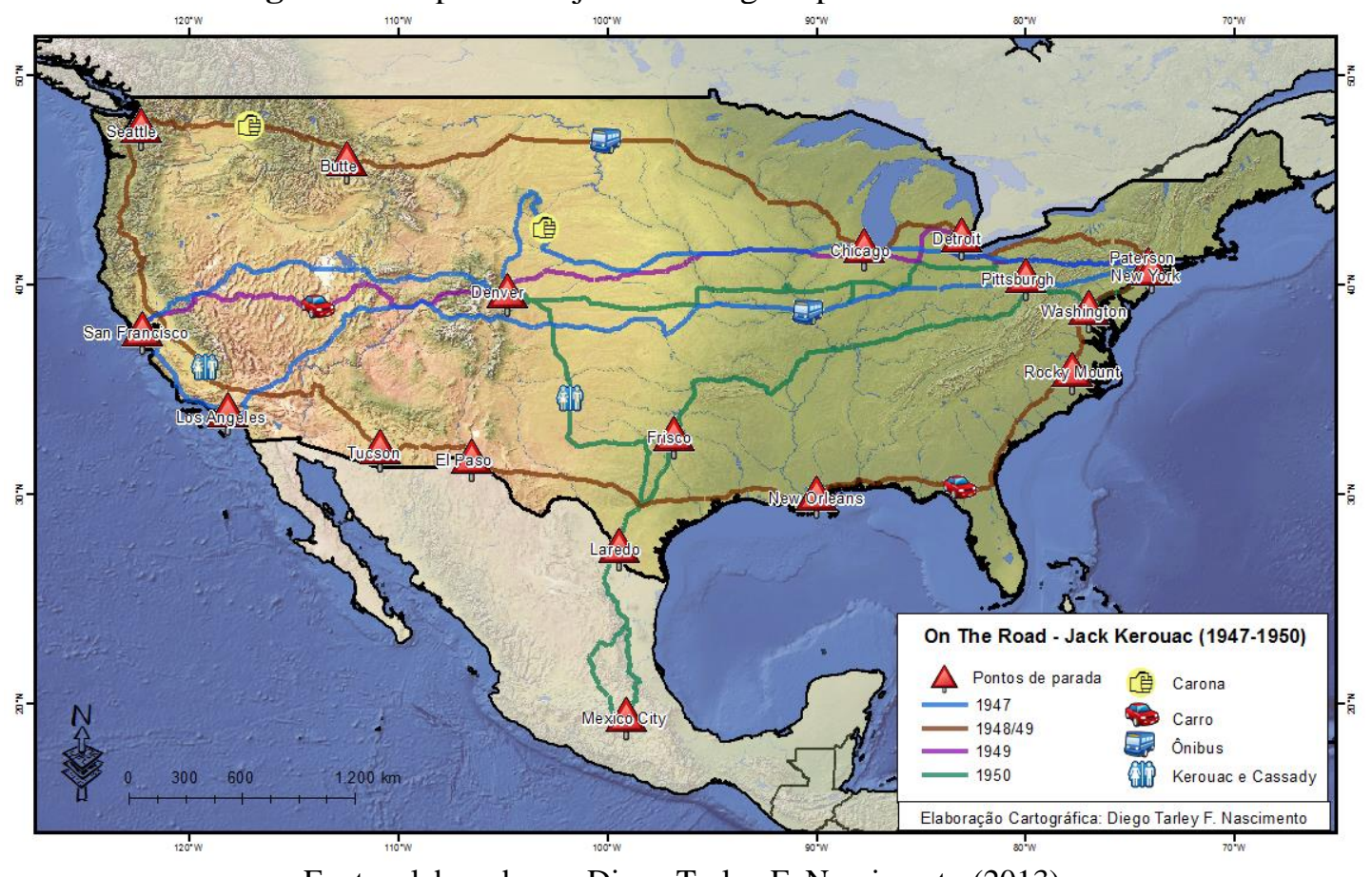

Fonte: elaborado por Diego Tarley F. Nascimento (2013).

Esta fascinação em percorrer as estradas de norte a sul, de leste a oeste e viceversa está em sintonia com a crença de existência das estradas identitárias. Estradas que 
são diversas, acolhedoras nas palavras de Dean dialogando com Sal: "Qual é a sua estrada, homem? - a estrada do místico, a estrada do louco, a estrada do arco-íris, a estrada dos peixes, qualquer estrada... Há sempre uma estrada em qualquer lugar, para qualquer pessoa, em qualquer circunstância” (KEROUAC, 2006, p. 305).

Também, como Sal confidencia a Dean, na viagem ele prefere "ler" a paisagem americana enquanto seguiam em frente. "Cada saliência, cada colina, cada planície mistificava meus anseios. Cruzamos o Novo México na escuridão da noite; na aurora descolorida estávamos em Dalhart, Texas; na desamparada tarde de domingo rodávamos pela monotonia de uma cidade atrás da outra de Oklahoma; ao entardecer era o Kansas" (op. cit., p. 135).

On the road, na tradução de Eduardo Bueno, publicado em 2006, pela L\&PM, contém 380 páginas. Consta de uma introdução do tradutor apresentando "a longa e tortuosa estrada profética”. Seguindo, apresenta On the road em cinco partes, nas quais Sal Paradise relata suas viagens na companhia do amigo Dean, suas percepções paisagísticas e experiências de vida nas estradas e em outras cidades norte-americanas. Fecha o livro com um posfácio escrito pelo tradutor intitulado "A estrada sem fim".

O livro On the road - pé na estrada, é fecundo para a geografia porque contém uma visão geográfica singular e, proporciona o conhecimento de um tipo de espaço muito comum: o lugar-móvel, criado pelas mobilidades. Conforme reflexões feitas por Lussault (2007) trata-se de realidades espaciais que possuem as características do lugar e que em seu deslocamento levam com elas outras realidades sociais. A partir dos lugares-móveis, os atores constroem uma experiência social do espaço muito particular. De fato, tal experiência está na relação com o espaço do lugar-móvel e, na relação visual com o espaço no seio do qual o lugar-móvel inscreve sua trajetória. Essa relação visual instaura uma relação cinética particular ao espaço. Ela se torna uma das modalidades padrão $d$ a espacialidade dos indivíduos e modifica em profundidade os esquemas clássicos de apreensão do espaço.

Ainda de acordo com este autor (2007), durante séculos, no seio da cultura moderna ocidental, havia três modos principais de relações visuais legítimas com o espaço: 1) zenital (como emblema, a carta); 2) frontal (como exemplo, a paisagem de pintura, em décor monumental, modelizando, sem dúvida, a primeira relação visual 
"moderna" do espaço, isto é, ele fixado na sua expressão estética canônica; 3) panorâmica, tendo o panorama como emblema.

Desde o século XIX, as formas culturais legítimas foram marcadas pela importância adquirida do fluxo, do movimento, do deslocamento, em particular, o urbano. Essa importância acentua-se, desde então, continuamente, até fazer na atualidade da mobilidade e da rapidez uma cultura específica, com seus valores e seus usos, tendendo a dominar e a espalhar as demais formas culturais. Essa cultura dá um lugar fundamental na definição pelo indivíduo de seu regime de atenção aos outros, às coisas, e de sua maneira de fazer suas atividades. Atualmente, esse regime e sua maneira de fazer são frequentemente ligados ao movimento e à velocidade, que condicionam as maneiras específicas de ver até produzir uma verdadeira estética particular. Exemplos da relação cinética acelerada estão presentes, sobretudo, no cinema de ação ou nos atuais jogos de vídeo.

$\mathrm{O}$ modo cinético acelerado provoca um descolamento espacial significativo. $\mathrm{O}$ outro-espaço do lugar-móvel torna-se o domínio do espaço da experiência espacial imediata do indivíduo. E ele, ao mesmo tempo, constitui o meio da relação com o espaço-outro, que envolve o lugar-móvel.

Considerar assim os lugares-móveis é apreendê-los pelo que eles são: lugares de vida essenciais; "quadros de experiências social cotidiana, nos quais nas fissuras os indivíduos testam o espaço, colocam em obra as tecnologias da distância e inventam as espacialidades" (LUSSAULT, 2007, p. 105).

$\mathrm{O}$ autor destaca ainda diversas paisagens, a partir de formas visuais ideal-típicas, presentes na nossa sociedade e modalidades específicas de leituras que elas sugerem. Dentre elas, a paisagem-movimento ligada à promoção da relação visual cinética acelerada, já comentada. A paisagem-movimento é, atualmente, voluntariamente organizada, por exemplo, pelos operadores das grandes empresas ferroviárias e rodoviárias. Ela "é marcada pelo deslocamento contínuo da sequência da paisagística diante do observador que, embora em movimento, parece ser um ponto fixo," afirma Lussault $(2007,139)$.

Esta concepção de mobilidade "move" a obra: 
olhei o mapa: um total de mil e seiscentos quilômetros, a maior parte no Texas até a fronteira com Laredo, e então mais mil e duzentos através do México inteiro até a enorme cidade próxima à rachadura do istmo e às escarpas de Oaxacam. Não conseguia sequer imaginar essa viagem. Era a mais fabulosa de todas! Já não era mais a velha rota Leste-Oeste, mas o Sul mágico! Tivemos uma visão do hemisfério ocidental inteiro descendo até a Terra do Fogo como uma cadeia montanhosa e nós mesmos flutuando por essa longa curva do mundo rumo a outros trópicos, outros mundos. 'Homem, finalmente encontramos AQUILO!', disse Dean com fé inabalável (KÉROUAC, 2006, p. 322).

E ainda:

Lá vamos nós! Inclinou-se sobre o volante e deu partida; estávamos de volta ao seu elemento natural, qualquer um podia perceber. Ficamos maravilhados, percebemos que estávamos deixando para trás toda a confusão, o absurdo, desempenhado a única função nobre de nossa época: mover-se. E nos movíamos. Passamos como uma flecha pelas misteriosas placas brancas que, em algum lugar na noite de Nova Jersey, dizem SUL (com uma fecha) e OESTE (com outra flecha) e pegamos o caminho que apontava para o sul, Nova Orleans! Era o que reluzia em nossas mentes (op. cit., 2006, p. 170).

\section{A POÉTICA DE ON THE ROAD}

É compreensivo supor que, mais que uma história, um romance propõe uma geografia. Além da temporalidade da narrativa, a partir da apresentação sucessiva de lugares escritos, o romance elabora uma "figura" que liga o espaço mais ou menos contínuo e coerente do romance. Ele nos revela ainda paisagens do mundo.

A palavra poética revela o mundo. Ela se associa à imagem poética que dá a ver uma imagem que agrega várias figuras. Cada uma delas traduz uma relação específica, como em On the road que fala sobre e dos USA. Para apreciar o lirismo, o olhar sensível e a prosa poética de Kérouac, comecemos por presentificar a paisagem, na ótica da natureza (rios, céus, vegetação, desertos, planícies e planaltos), a paisagem urbana (os homens e as paisagens construídas). Como já foi dito, Kérouac recorre ao jazz à guisa de metáfora estilística para comunicar a experiência da mobilidade frenética do On the road. Cabe ressaltar que metáfora é uma figura de linguagem. Nela há o emprego de uma palavra ou uma expressão, em um sentido que não é muito comum, em uma relação de semelhança entre dois termos. É usual em textos literários. 


\subsection{Os rios: amarras, fúnebre, históricos e perfumados}

A literatura pode exprimir as contradições, os paradoxos de um mundo submisso às ideias e às ideologias dominantes. O recurso ao romance, para uma reflexão geográfica é para apreender o novo ou o diferente sobre a escritura dos lugares. Descrevendo a paisagem, Kérouac nos apresenta uma paisagem poética dos rios, das planícies e das montanhas. Sua linguagem é metafórica porém, falam de geografia plena de percepção. Alguns exemplos nas representações dos rios Susquehanna, Misssissipi e Hudson:

Se você jogar uma rosa no rio Hudson, em suas misteriosas nascentes nas Adirondacks, imagine todos os lugares por onde ela viajará antes de desaparecer no mar para sempre - pense no sublime vale do Hudson (KÉROUAC, 2006, p. 29).

Caminhamos uns 11 quilômetros ao longo do fúnebre Susquehanna. É um rio aterrador. Nas duas margens seus penhascos são repletos de arbustos, dependurados como fantasmas felpudos sobre águas desconhecidas. Trevas da noite recobriam tudo. Às vezes surgia o clarão avermelhado das locomotivas que estavam sobre os trilhos do outro lado do rio, iluminando penhascos horrendos. (op. cit., 2006, p.137).

[...] 'vamos sair e curtir o rio e as pessoas e aspirar todos os perfumes do mundo', disse Dean [...] Nós o seguimos. Nos inclinamos na balaustrada e olhamos o grande pai moreno de todas as águas escoando desde o meio da América como uma torrente de almas penadas transportando toras de madeira de Montana e lodo dos vales de Dakota e do Iowa e objetos que submergiram em Three Forks, onde os segredos começam no gelo (op. cit., p. 178).

O que é o rio Mississipi? - Um torrão lavado na noite chuvosa, um suave transbordamento das margens gotejantes do Missouri, um dissolver, uma cavalgada da corrente acima do leito eterno das águas, uma contribuição às espumas castanhas, uma jornada através de vales sem fim, e árvores, e diques, sempre abaixo, sempre descendo, por Memphis, Greenville, Eudora, Natchez, Porto Allene Port Orleans e Port of the Deltas, por Potash, Venice e o Grande Golfo da Noite, pelo mundo afora (op. cit., p.197).

Para Kerouac, os rios desvelam várias facetas. Eles são representados pela sua função, pelo seu valor histórico, pelos sentimentos que inspiram integrando aspectos psicológicos e emoção espiritual e remetendo o leitor à paisagem espiritual citada por Andreotti (2008).

\subsection{A vastidão e a grandiosidade dos espaços naturais}


O relevo surge imponente, misterioso e revelador de diversidade espacial, devido à vegetação, aos cursos fluviais, aos desertos, às cidades e aos campos de cultivo.

[...] Escureceu num instante. Todos tomaram um trago e, de repente, olhei para os lados e os campos verdejantes das fazendas do Platte começaram a desaparecer, e no lugar deles surgiram planos e amplos desertos de areia e arbustos ressequidos se esparramando tão longe quanto os olhos pudessem alcançar (KÉROUAC, 2006, p. 47).

Eu julgava que toda vastidão selvagem da América se concentrava no Oeste, até que o Fantasma do Susquehanna me provou que não era bem assim. Não, também havia amplitudes selvagens no Leste. Era a mesma imensidão qual Bem Franklin se arrastara no tempo dos carros de boi quando era agente do correio [...] quando Bradford abriu sua estrada e seus homens subiram ruidosamente por ela construindo suas cabanas de toras. Para aquele homenzinho, não existiam os amplos espaços abertos do Orizona, só a vastidão repleta de arbustos emaranhados do leste da Pensilvânia, Maryland e Virgínia, e as estradas secundárias, escuras estradas do interior serpenteando entre rios sombrios como o Susquehanna, Monongahela, o velho Potomac e o Monocacy (op. cit., p.138).

Estávamos descendo a planície costeira em direção a Mobile; à nossa frente grandes nuvens do golfo do México pairavam nos céus (op. cit., 176).

Longe, em frente, tremeluziam as luzes distantes de El Paso e Juarez, disseminadas num vale tão extraordinariamente grande que se podiam avistar várias linhas férreas com trens soprando suas fumaças em todas as direções ao mesmo tempo, como se fosse o Vale do Mundo (op. cit., p. 203).

É a contemplação, mais que experiência lógica, que é acionada quando se faz uma leitura estética. Tal leitura emerge da observação, do imaginário do físico-natural com suas variações, mutações zonais sem se esquecer da obra do homem: estradas, centros habitados, locomotivas, sinais da modernidade, integrados a esta paisagem que se torna cultural.

\subsection{Os campos e cultivos - paisagens hibridas e móveis}

Paisagens culturais são ricas nos relatos de Sal. O seu olhar dirige-se para perceber a paisagem carregada de sentido, investida de significados por aqueles que vivem nela ou que a descobrem. Neste processo, Duncan opina, dizendo que "[...] a 
paisagem é lida como um texto, e então atua como um elemento de transmissão, reproduzindo a ordem social" (DUNCAN, 2004, p. 111).

Seguem alguns trechos do livro de Kérouac (2006), que comprovam isso:

\begin{abstract}
Nos inclinamos e começamos a colher o algodão. Era lindo. Do lado de lá do campo ficavam as barracas, além delas os áridos e terrosos campos de algodão se estendendo a perder de vista, até as colinas do arroio barrento e, mais adiante, as serras com seus cumes nevados sob o ar azulado da manhã (KÉROUAC, 2006, p. 126).

Curvados e melancólicos, o velho casal de negros labutava em suas fileiras, e seus sacos iam engordando de algodão. Minhas costas começaram a doer. Mas era lindo se ajoelhar e se esfolar naquela terra. Quando sentia vontade de descansar, eu o fazia, recostando minha cara num travesseiro de terra úmida e escura. Pássaros cantarolavam marcando o compasso (op. cit., p. 127).

Caminhei pela estrada rumo a Sabinal, comendo nozes de uma nogueira negra à beira do caminho. Fui para a linha férrea me equilibrando sobre os trilhos da Southern Pacific. Passei por uma caixa d'água e por uma fábrica. Alguma coisa terminava ali (op cit., p. 134).
\end{abstract}

Breve, a paisagem testemunha a aventura do homem na superfície da terra e qualquer marca por ele introduzida significa um diferente valor cultural. Técnicas, crenças religiosas e ideológicas perpassam cada paisagem, por isso, as paisagens possuem significados simbólicos e estão, também, carregadas de ideologias.

\title{
5.4. Singulares e diversas cidades na paisagem - movimento
}

Percorrer a cidade, absorver seu ambiente é estabelecer uma comunhão com ela. Para Sal e Dean, cada instante nas cidades tem mais do que os olhos podem ver, do que o olfato pode sentir ou de que os ouvidos podem escutar. Cada instante contém sentimentos, associações a significados, tendo uma constante construção de significações. "A cidade é o que é visto, porém mais ainda, o que pode ser sentido", afirma Castrogiovanni (2000, p. 25).

Conforme Almeida (2012), cada cidade fala à sua maneira. Os olhares dos passantes captam o discurso sem voz. Alguns emocionam pelo encanto da iconicidade e outros causam repulsas. A excitação que emerge do primeiro olhar é esta disposição paisagística da cidade. 
No romance, Kérouac consegue propor uma personalidade dos lugares, na sua dimensão poética entre o real e a ficção como ele apresenta sobre as cidades norteamericanas visitadas. Assim, com base no On the road, uma grosseira tipologia da percepção citadina de Kérouac: cidades e natureza, cidades de sons e cheiros, cidade da topofobia e cidades de cores, luzes e cotidiano, próprias das personalidades dadas à cada uma das cidades. Também, evidencia como Kérouac fez falar o espaço urbano, tornando seu texto-lugar. Para Brosseau (1996) a metáfora texto-lugar é utilizada para emergir o lugar/cidade. O olhar vagueia sobre palavras e estilo, sintaxe e cadencia que se tornam tangíveis, quase palpáveis na medida que passa de uma cidade a outra. São texto-lugares espelhando o "pé na estrada".

\subsection{Cidades e Natureza}

[...] Agora sim podia ver a silhueta de Denver agigantando-se à minha frente como uma Terra Prometida, lá fora entre as estrelas, através das pradarias do Iowa e pelas planícies de Nebraska, e tive uma visão grandiosa de São Francisco mais adiante, jóias luzindo à noite (KÉROUAC, 2006, p. 34).

De repente percebi que estava na Califórnia. Ar cálido e próspero soprando entre as palmeiras - ar que se pode beijar-e as palmeiras, elas mesmas. E então, ao longo do célebre rio Sacramento por uma superfreeway até as montanhas outra vez; para cima e para baixo e, subitamente, a vasta amplitude da baia (era justamente antes do amanhecer) com as sonolentas luzes de Frisco tremeluzindo em suas águas (op. cit., p. 84).

Chegamos a Saint Louis ao meio-dia. Dei uma caminhada ao longo do rio Mississippi e observei as toras de madeira que vêem flutuando desde Montana, no Norte - toras magníficas e sua espantosa odisséia através de nosso sonho continental. Velhos barcos a vapor com seus ornamentos ainda mais rebuscados e murchos pelas intempéries assentados na lama e habitados por ratos. Grandes nuvens do entardecer pairavam sobre o vale do Mississippi. (op. cit., p. 135).

\subsection{Cidades de sons e cheiros}

$\mathrm{O}$ ar era tão perfumado em Nova Orleans que parecia vir em écharpes macias; podia-se sentir o cheiro do rio e mesmo o cheiro das pessoas, e da lama e do melado, e todos os tipos de exalações tropicais com o nariz subitamente retirado do gelo do inverno setentrional. (KÉROUAC, 2006, p. 178).

[...] "Raios, é o Festival do Oeste Selvagem", disse Slim. Multidões de executivos gordos com chapéus enormes e botas texanas, com suas pesadas esposas vestidas de vaqueiras, percorriam as calçadas de madeira da velha Cheyenne, barulhentos e afobados. Lá longe reluzia a luz viscosa dos bulevares do centro novo de Cheyenne, mas a 
celebração concentrava-se na parte velha. Estouravam tiros de festim. Os salões estavam abarrotados até a calçada (op. cit., p. 54).

[...] e, antes que pudéssemos perceber, já estávamos passando pelos mercados que vendem frutas por atacado nos arredores de Denver; havia chaminés, fumaça, vias férreas; prédios avermelhados, de tijolos à vista, e os edifícios de concreto do centro da cidade, afastados e cinzentos; e aqui estava eu em Denver (op. cit., p. 59).

Sacolejamos por cima dos trilhos do trem em Fresno e chegamos às ruas endoidecidas do bairro mexicano; grupos de garotas mexicanas se pavoneando metidas em slacks, mambo estourando nas jukebox; as luzes da rua estavam ornamentadas como se fosse Noite das Bruxas. Fomos a um restaurante mexicano e comemos tacos e feijão amassado enrolado em tortillas, uma delícia (op. cit., p. 124).

\subsection{Cidade da topofobia}

[...] Eu podia ouvir tudo, os sons da rua se misturavam ao zumbido do néon de nosso hotel. Nunca me senti tão triste em toda minha vida. LA é a mais solitária e mais brutal de todas as cidades americanas. Em Nova York fica frio pra cacete durante o inverno, mas nas ruas, em algum lugar, existe um sentimento de camaradagem. LA é uma selva (op. cit., p. 115).

\subsection{Cidades de cores, luzes e cotidiano}

[Em Bakersfield] cruzamos a linha férrea da Southern Pacific e fomos para o bairro mexicano. A noite caíra e agora a estreita rua mexicana era uma válvula reluzente cheia de luzes: marquises de cinema, frutarias, arcadas vulgares, bazares e centenas de caminhões frouxos e calhambeques enlameados. Famílias inteiras de mexicanos colhedores de frutas perambulavam comendo pipocas (KEROUAC, 2006, p. 120).

De repente, lá estava eu na Times Square. Tinha viajado 12 mil quilômetros pelo continente americano e estava de volta à Times Square; e ainda por cima bem na hora do rush observando com meus inocentes olhos de estradeiro a loucura completa e zunindo fantástico de Nova York com seus milhões e milhões de habitantes. Atropelando uns aos outros sem cessar em troca de uns tostões, um sonho maluco pegando, agarrando, entregando, suspirando, morrendo, e assim poderia ser enterrado naquelas horrendas cidades-cemitérios que ficam além de Long Island (op. cit., p. 140).

A enfumaçada Nova Orleans retrocedia de um lado; a velha e sonolenta Algiers com seus arborizados arredores aluvionais vinha ao nosso encontro do outro lado. Negros estavam trabalhando no entardecer calorento, carregando as fornalhas da balsa, que já estavam rubras e quase faziam nossos pneus derreterem (op. cit., p. 178).

Tracy é uma cidade ferroviária; os guarda-freios engoliam uns pratos intragáveis nos restaurantes ao lado da linha férrea. Trens zuniam cruzando o vale. $\mathrm{O}$ sol rubro se punha lentamente. Os nomes mágicos do vale se sucediam: Manteca, Madera e todo o resto. E logo veio o crepúsculo, um crepúsculo cor-de-vinho, uma penumbra púrpura dispersa sobre arvoredos de tangerina e extensas plantações de melão. 
O sol estava com a mesma cor de uvas esmagadas misturadas com Borgonha tinto; os campos possuíam a mesma tonalidade dos amores e mistérios espanhóis (op. cit., p. 108).

Tucson está situada numa bela região rural entre arbustos e à margem do rio, dominada pela serra da Catalina. A cidade era uma grande loja de materiais de construção, as pessoas na rua, apressadas, loucas, ambiciosas, ocupadas, alegres; varais espalhados pelos quintais, trailers; as ruas fervilhantes e embandeiradas no centro. Tudo muito californiano (op. cit., p. 208).

[...] começamos a rodar pelo sopé da colina de Oackland e, repentinamente, atingimos o cume do morro e vimos, esparramada à nossa frente, a fabulosa cidade de São Francisco, clara, sobre suas onze colinas místicas, com o Pacífico azulado e sua muralha elevada com a plantação de batatas ao longe, sob a névoa, e fumaça e resplendor no fim da tarde do tempo (op. cit., p. 213).

A cidade presentificada no On the Road, independentemente de sua localização, de seu tamanho, ou qual seja sua função ou tipologia se constrói pela acumulação de imagens múltiplas e variadas, reais e imaginadas que atraem, criam o desejo de conhecê-las, de penetrar em suas ruas e praças e, de descobrir seus mistérios.

As cidades descritas por Sal Paradise configuram-se como lugares. A noção de lugar nos diz Monteiro (2002), embora sendo a obra de imaginação e criação literária, contém uma "verdade" que pode estar além daquela advinda de uma cuidadosa observação. As cidades descritas por Kérouac contém "verdade", resultado da percepção que leva a considerá-la um texto-lugar. Cabe bem a reflexão de Suzuki (2005, p. 138), referindo-se aos poemas de Leminski sobre Curitiba: "neles, aparece uma voz lírica que pouco discute sobre o movimento de produção da cidade, mas a retrata no seu instantâneo volátil de metamorfose constante".

\section{6. À GUISA DE CONCLUSÃO...}

O propósito deste artigo foi compreender a apreender a geografia presente no texto romanesco. Partiu-se do princípio que os romancistas têm um olhar sensível e habilidade descritiva para exprimirem as estruturas ecológica, socioespacial que se

superpõem e imbricam. É, portanto, uma geografia poética que está em análise. A metáfora do texto oferece possibilidades interpretativas mais flexíveis, pois o texto é o teatro de uma mediação, e há um ganho cognitivo considerável. 
Cabe destacar que as representações feitas por Kérouac e, mesmo por mim, implicaram um recorte, uma seleção mais ou menos deliberada de certos elementos de um conjunto mais vasto para realçar essa geografia. Elas são evidências que tanto a literatura quanto a geografia contribuem para o conhecimento de si e do outro, constituem-se reflexão do homem sobre seu estar no mundo e em sua relação com o mundo pela forma de se organizar.

O romance apresenta o espaço, a paisagem e os lugares. Os lugares e paisagens em movimento apresentados por Kérouac, possuem e falam de uma geograficidade, comentada por Dardel (2011). Kérouac procura fazer dialogar o "espaço do texto" com o "espaço geográfico" resultando em uma geografia poética dos textos-lugares.

On the road possui uma narrativa veloz, instigando ao leitor a seguir Sal e Dean pela trilha vertiginosa, em pura exaltação, adentrando por geografias norte-americanas. Neste sentido, a literatura, como já foi dito, é considerada uma fonte de imaginação científica, de estímulo intelectual, capaz de despertar os desejos, de influenciar os gostos e disparar a ação. Ela dá uma visão particular do Mundo e revela a estrutura espaço-temporal da existência do homem.

As produções literárias, ficcionais ou poéticas, em si mesmas reproduzem, reafirmam e fortalecem valores, leis, crenças e sentimentos que alicerçam a visão de mundo de um povo. Mensagens têm sido transmitidas pela literatura. Machado de Assis, Guimarães Rosa, Octavio Paz, Garcia Marquez, Jorge Amado trazem instigantes reflexões sobre costumes, justiça, amor, morte, conflitos... Enfim, produções literárias estão prenhes de uma geografia sensível.

Kérouac testemunha um espaço estadunidense grandioso, no qual ele observa as mudanças paisagísticas, o espaço-movimento, as marcas da história, os elementos urbanos simbólicos do triunfalismo arrogante do pós-guerra. Kérouac, por meio de uma epopeia vivida ao volante do automóvel, lembra os espaços naturais ainda a serem ocupados ou engolidos pelas cidades e campos de plantações e as cidades pujantes e efervescentes (ANCTIL et. al., 1990). Os Estados Unidos estão em constante movimento. O movimento é uma instancia fundamental da produção e emergência do sentido do visto e vivido.

Por estar diretamente relacionada à vida da qual é imagem, uma descrição deambulatória, ou cinética, On the road traz questionamentos, abala verdades e instiga a 
ver que há um mundo lá fora. Ele nos convida a enfrentar o novo, o desconhecido. Sem dúvida, a obra de Kérouac traz uma fascinante aventura geográfica por uma América incógnita, uma América dada a descobrir por aqueles que aventuram por suas estradas poéticas.

\section{REFERÊNCIAS}

ALMEIDA, Maria Geralda. O turismo e a produção de imagens e identidades das cidades contemporâneas. In: ALMEIDA, Maria Geralda; TEXEIRA, Karla Anielly; ARRAIS, Tadeu P. Alencar. (Orgs.). Metrópoles: Teoria e pesquisa sobre a dinâmica metropolitana. Goiânia: Cânone, 2012, 47-59.

ANCTIL, Pierre; DUPONT, Louis; FERLAND, Rémi; WADDELL, Eric. Un Homme grand: Jack Kérouac à la confluence des cultures.Ottawa: Carleton University Press, 1990.

ANDREOTTI, Giuliana. Per un 'architettura del paesaggio. Trento. Valentina Trentini, editore, 2008.

BROSSEAU, Marc. Des Romans-Géographes. Essai. Paris : L’Haramattan, 1996.

CALOBREZI, Edna T. Uma abordagem do Texto Literário. In: GOMES, André L. (Orgs). Entre Textos. Ensaios sobre Literatura, Cinema, Semiótica, Educação e Música. São Paulo : Antiqua, 2005, p. 79-96.

CANDIDO, Antonio. O direito à literatura. Vários escritos. São Paulo/Rio de Janeiro: Duas Cidades/Ouro sobre azul, 2004.

CASTROGIOVANNI, Antonio Carlos. Turismo e ordenação no espaço urbano. In: CASTROGiOVANNI, A. C. (Org.). Turismo urbano. São Paulo: Contexto, 2000, p. 2332.

DARDEL, Eric. O Homem e a Terra: natureza e a realidade geográfica. São Paulo: Perspectiva, 2011.

DUNCAN, James. A paisagem como sistema de criação de signos. In: CORREA, R. L. ROSENDAHL, Z. (Org.). Paisagens, textos e identidade. Rio de Janeiro: EdUERJ, 2004, p. 91-132.

KEROUAC, Jack. On the Road. Pé na Estrada. Tradução de Eduardo Bueno. Porto Alegre: L\&PM, 2006. 
KOZEL, Salete. Geopoética das paisagens: olhar, sentir e ouvir a "natureza". Caderno de Geografia, v. 22, n.37, 2012. p. 65-78.

LUSSAULT, Michel. L'Homme spatial. La construction sociale de l'espace humain. Paris: Ed.Seuil, 2007.

MONTEIRO, Carlos Augusto F. O mapa e a trama. Ensaios sobre o conteúdo geográfico em criações romanescas. Florianópolis: Ed. UFSC, 2002.

PITTE, Jean-Pierre. Géographie Culturelle. Paris: Fayard, 2006.

SUZUKI, Julio C. Geografia e Literatura :uma leitura da cidade na obra poética de Paulo Leminski. Revista da ANPEGE., 2005, ano 2, n. 2, p. 115-138.

TISSIER, Jean-Luc. Geographie et littérature. In: BAILLY, Antoine; FERRAS, Robert ; PUMAIN, Denise (Eds). Encyclopédie de Géographie. Paris, Economica, 1992, p. 235256.

WHITE, Kenneth. Le Plateau de l'Albatros: Introduction a la Geopoétique. Paris: Grasset et Fasque-lle, 1998.

Recebido em 05/08/2018.

Aceito em 28/10/2018.

Publicado em 10/09/2020. 